\title{
Kajian Sistem Pengelolaan Usaha Peternakan Sapi Potong di Kabupaten Sijunjung
}

\section{The Study on System Management of Beef Cattle Business in Sijunjung Regency}

\author{
Riza Andesca Putra' dan Vivi Hendrita ${ }^{1}$ \\ 'STIPER Sawahlunto Sijunjung \\ Muaro Sijunjung \\ rizaandescaputra18@gmail.com
}

\begin{abstract}
Diterima : : 10 Agustus 2019
Disetujui : 25 Agustus 2019

Diterbitkan : 31 Agustus 2019
\end{abstract}

\begin{abstract}
Abstrak: Penelitian ini bertujuan untuk mengetahui karakteristik peternak, sistem pemeliharaan, sistem pengelolaan pakan, sistem pengelolaan reproduksi, dan sistem pemasaran ternak sapi potong di Kabupaten Sijunjung. Penelitian ini dilakukan di wilayah Kabupaten Sijunjung yaitu peternak di daerah terpilih pada bulan Juni sampai Juli 2019. Penelitian ini menggunakan metode survey dengan respondennya adalah peternak sapi potong yaitu 44 orang responden. Dari hasil penelitian dapat disimpulkan bahwa usaha peternakan sapi potong di Kabupaten Sijunjung masih usaha sampingan masyarakat (93,18\%), jumlah ternak yang dipelihara 1-3 ekor per peternak (77,27\%) dan pada umumnya merupakan sapi milik sendiri (61,36\%). Sistem pemeliharaan ternak pada umumnya dengan sistem semi intensif (45,45\%) dengan pakan yang diberikan adalah hijauan dengan merumput ditambah hijauan hasil pemotongan (47,73\%). Sistem reproduksi menggunakan kawin alam dengan jantan pemacek (50\%) dan inseminasi buatan (50\%) serta pemasaran ternak masih melalui toke ternak/pedagang pengumpul $(88,64 \%)$.
\end{abstract}

Kata Kunci: pengelolaan, peternakan sapi potong, sistem

Abstract: The research was conducted in the area of Sijunjung Regency which aims to determine the characteristics of the farmer, raising systems, feed management systems, reproductive management systems, and marketing systems of beef cattle were carried out June to July 2019. It used a survey method with 44 beef cattle farmers as the respondents. The results showed that the beef cattle business in Sijunjung Regency was still as a community side business (93.18\%), the number of ownerships of beef cattle was 1-3 head of cattle per farmer $(77.27 \%)$ and generally that beef cattle own by them self $(61,36 \%)$. The raising system generally was still in a semiintensive system (45.45\%) with the feed given by forage in grazing system and cutting system (47.73\%). The reproductive system used natural mating (50\%) and artificial insemination (50\%). The marketing of beef cattle was sold to the collector traders (88.64\%).

Keywords: management, beef cattle farming, system

\section{Pendahuluan}

Provinsi Sumatera Barat adalah salah satu pusat pengembangan peternakan sapi potong di Indonesia. Setiap pelaksanaan program swasembada daging sapi nasional, Provinsi Sumatera Barat selalu menjadi daerah pendukung utama. Salah satu daerah pengembangannya adalah Kabupaten Sijunjung. Kabupaten ini terletak dalam posisi yang strategis yaitu dilalui jalan lintas Sumatera dan berbatasan dengan Provinsi Riau dan Jambi, dua provinsi yang masih minus sapi dan biasanya menjadi pasar potensial para peternak sapi asal Sumatera Barat.
Kabupaten Sijunjung memiliki wilayah yang cukup luas 3.130,80 km2 atau sekitar 313.080 Ha dengan 8 kecamatan. Sebagian besar masyarakat di kabupaten ini menggantungkan hidupnya pada sektor pertanian, yaitu 49,66\% dari angkatan kerja. Komoditi pada sektor pertanian tersebut antara lain padi sawah, karet, kelapa sawit, buah-buahan dan peternakan. Pada tahun 2014, populasi sapi di daerah ini adalah 13.465 ekor dengan rumah tangga pemelihara ternak 5.925 KK [1].

Di kabupaten ini terdapat salah satu pasar ternak terbesar di Sumatera Barat yaitu Pasar Ternak Palangki. Di pasar ini berkumpul para pedagang dan pembeli sapi lintas kota di Sumatera Barat dan lintas 
provinsi, seperti: dari Riau, Jambi, Bengkulu dan Lampung. Hari pasarnya adalah sabtu, namun tiap harinya juga masih terdapat jual beli sapi dengan frekuensi yang lebih kecil.

Kabupaten Sijunjung memiliki karakter sumber daya manusia peternak yang tergolong cukup baik dalam upaya pengembangan sapi potong. Hal tersebut berdasarkan bahwa umumnya peternak sapi potong di Kabupaten Sijunjung masih berusia produktif yaitu berumur $25-55$ tahun $(72,2 \%)$, berjenis kelamin laki-laki $(69,4 \%)$, memiliki pengalaman beternak sapi potong 5-10 tahun (41,7\%). Walaupun di sisi lain pada umumnya berpendidikan $\mathrm{SD} /$ sederajat $(55,6 \%)$ [2].

Ketersediaan lahannya juga mendukung, yaitu dengan Nilai Indeks Daya Dukung (IDD) nya adalah 6,8. Ini artinya Kabupaten Sijunjung berada di wilayah AMAN dalam pengembangan peternakan sapi potong karena memiliki IDD > 2. Dengan hitungan ini, wilayah Kabupaten Sijunjung dapat menampung ternak ruminansia sebesar 85.585,7 ST. Saat ini populasi ternak ruminansia adalah $\mathbf{2 5 . 2 4 4 , 5}$ ST. Dengan demikian di Kabupaten Sijunjung masih bisa dilakukan penambahan populasi ternak ruminansia mencapai 6o.341,2 ST. Maka untuk ternak sapi potong dapat dilakukan penambahan populasi sebesar 29.627,5 ST lagi [2].

Agar pelaksanaan pembangunan tepat sasaran dan sesuai dengan kebutuhan riil, data-data di atas mesti dilengkapi dengan beberapa data lainnya. Diantaranya tentang sistem pengelolaan usaha yang dilakukan peternak sapi potong di Kabupaten Sijunjung. Data ini menjadi penting karena menggambarkan bagaimana masyarakat peternak di kabupaten ini menganggap dan memperlakukan sapinya. Dengan demikian, informasi potensi yang dimiliki Kabupaten Sijunjung menjadi lebih lengkap sehingga kegiatan pengembangan peternakan sapi yang dilakukan juga dapat berjalan dengan lebih baik.

\section{Metode Penelitian}

\subsection{Tempat dan Waktu}

Penelitian ini dilakukan di wilayah Kabupaten Sijunjung yaitu peternak pada daerah terpilih. Penelitian dilaksanakan pada bulan Juni sampai Juli 2019 .

\subsection{Metode Pelaksanaan}

Penelitian ini menggunakan metode survey. Survey dilakukan dengan cara pengamatan dan wawancara langsung dengan responden. Dalam hal ini respondennya adalah peternak sapi potong yang ada di Kabupaten Sijunjung.

\subsection{Populasi dan Sampel}

Untuk penelitian ini, secara purposive sampling diambil dua kecamatan dengan jumlah peternak sapi terbesar dan dua kecamatan dengan jumlah peternak sapi terkecil di Kabupaten Sijunjung sebagai sampel penelitian. Maka jumlah populasi pada penelitian ini seperti yang tertera pada Tabel 1 berikut:

Tabel 1. Populasi penelitian

\begin{tabular}{clc}
\hline No & Nama Kecamatan & $\begin{array}{c}\text { Jumlah Rumah Tangga } \\
\text { Peternak (KK) }\end{array}$ \\
\hline 1 & Kamang Baru & 1.290 \\
2 & Sijunjung & 1.277 \\
3 & Lubuk Tarok & 381 \\
4 & IV Nagari & 47 \\
\hline & Total & 2.995 \\
\hline
\end{tabular}

Sumber: Data diolah

Kemudian penentuan jumlah sampel menggunakan rumus Slovin sebagai berikut:

$$
\mathrm{n}=\frac{N}{1+N d^{2}}
$$

Dimana :

$$
\begin{aligned}
& \mathrm{n}=\text { Jumlah sampel } \\
& \mathrm{N}=\text { Jumlah populasi } \\
& \mathrm{d}^{2}=\text { Presisi yang ditetapkan }(15 \%)
\end{aligned}
$$

maka :

$$
\begin{aligned}
\mathrm{n} & =\frac{2.995}{1+\left(2.995 \times 0,15^{2}\right)} \\
& =43,8 \\
& =44 \text { (dibulatkan) }
\end{aligned}
$$

Tingkat ketelitian atau keyakinan yang dikehendaki pada penelitian ini adalah $85 \%$ atau dengan tingkat presisi 15\%. Hal ini diambil atas dasar pertimbangan luas wilayah dan kemampuan peneliti dalam melakukan penelitian. Jumlah sampel tersebut selanjutnya diambil kembali secara purposive $(70 \%$ dari kecamatan dengan RT peternak terbesar dan 30\% dari kecamatan dengan RT peternak terkecil) sehingga didapatkan sebaran sampel per kecamatannya seperti pada Tabel 2 berikut:

Tabel 2. Sebaran Sampel Penelitian

\begin{tabular}{clcc}
\hline No & $\begin{array}{c}\text { Nama } \\
\text { Kecamatan }\end{array}$ & $\begin{array}{c}\text { Populasi } \\
\text { (KK } \\
\text { Peternak) }\end{array}$ & $\begin{array}{c}\text { Sampel per } \\
\text { Kecamatan (KK) }\end{array}$ \\
\hline $\mathbf{1}$ & Kamang Baru & $\mathbf{1 . 2 9 0}$ & $\mathbf{1 5}$ \\
$\mathbf{2}$ & Sijunjung & $\mathbf{1 . 2 7 7}$ & 15 \\
3 & Lubuk Tarok & 381 & 7 \\
4 & IV Nagari & 47 & 7 \\
\hline & Jumlah & 2.995 & 44 \\
\hline
\end{tabular}

Kemudian untuk menentukan sampel penelitian di lapangan, digunakan metode Snowball Sampling

\subsection{Variabel Penelitian}
a) Karakteristik peternak
b) Sistem pemeliharaan
c) Sistem pengelolaan pakan
d) Sistem pengelolaan reproduksi
e) Sistem Pemasaran 


\subsection{Analisis Data}

Semua data akan dianalisis dengan metoda deskriptif kualitatif. Penelitian kualitatif adalah suatu penelitian yang ditujukan untuk mendeskripsikan dan menganalisis fenomena, peristiwa, aktivitas sosial, sikap, kepercayaan, persepsi, pemikiran orang secara individual maupun kelompok. Data dihimpun dengan pengamatan yang seksama, mencakup deskripsi dalam konteks yang mendetil disertai catatan hasil wawancara yang mendalam, serta hasil analisis dokumen dan catatan-catatan [3]. Ini digunakan untuk menganalisis semua variabel

\section{Hasil dan Pembahasan}

\subsection{Kondisi Umum Daerah Penelitian}

Kabupaten Sijunjung merupakan salah satu dari 19 (Sembilan belas) kabupaten/kota di bagian Selatan Provinsi Sumatera Barat, terletak diantara $0^{\circ} 18^{\prime} 43^{\prime \prime} \mathrm{LS}$ - $1^{\circ} 41^{\prime} 46^{\prime \prime} \mathrm{LS}$ dan $100^{\circ} 46^{\prime} 50^{\prime \prime} \mathrm{BT}-101^{\circ} 53^{\prime} 50^{\prime \prime} \mathrm{BT}$ dengan ketinggian dari permukaan laut antara 100 - 1.250 meter [1]. Kabupaten Sijunjung berada di bagian Timur Provinsi Sumatera Barat, pada jalur utama yang menghubungkan Provinsi Riau dan Provinsi Jambi. Mengingat letaknya di persimpangan jalur tersebut, Sijunjung merupakan jalur ekonomi dan jalur pariwisata. Secara administratif wilayah Kabupaten Sijunjung dengan luas 313.080 Ha meliputi 8 Kecamatan, 61 Nagari dan 1 desa dengan 263 Jorong, yang wilayahnya berbatasan dengan:

$\begin{array}{ll}\text { Sebelah Utara } & \text { : Kabupaten Tanah Datar } \\ \text { Sebelah Selatan } & \text { : Kabupaten Dharmasraya } \\ \text { Sebelah Barat } & \text { : Kabupaten Solok dan Kota } \\ & \text { Sawahlunto } \\ \text { Sebelah Timur } & \text { : Kabupaten Kuantan Singingi, } \\ & \text { Provinsi Riau }\end{array}$

Secara Topografi Kabupaten Sijunjung merupakan rangkaian bukit barisan yang memanjang dari arah barat laut - tenggara. Morpologi daerah dibagi menjadi 3 (tiga) bagian, yaitu terjal pada bagian barat dan timur, dataran dibagian tengah dan perbukitan landai yang terletak diantaranya.

Ditinjau dari ketinggian, dominasi wilayah Kabupaten Sijunjung berada pada ketinggian terendah antara 120 - $130 \mathrm{~m}$ di atas permukaan laut dan tertinggi antara 550 - 930 m. Kabupaten Sijunjung secara keseluruhan berada pada ketinggian terendah dan tertinggi sekitar 100-meter sampai 1.50o-meter dari permukaan

Kondisi iklim di Kabupaten Sijunjung tergolong pada tipe tropis basah dengan musim hujan dan kemarau yang silih berganti sepanjang tahun. Keadaan iklimnya adalah temperatur dengan suhu minimum $21^{\circ} \mathrm{C}$ dan suhu maksimum $37^{\circ} \mathrm{C}$. Rata-rata curah hujan berdasarkan 6 titik tempat pemantauan 13,61 mm/hari untuk tiap bulannya.

\subsection{Karakteristik Peternak}

Penelitian yang telah dilakukan sebelumnya, ditemukan bahwa peternak sapi di Kabupaten Sijunjung memiliki karakter sumber daya manusia yang tergolong cukup baik. Hal tersebut berdasarkan pada bahwa umumnya peternak sapi potong di Kabupaten Sijunjung masih berusia produktif yaitu berumur 25-55 tahun (72,2\%), berjenis kelamin lakilaki $(69,4 \%)$, memiliki pengalaman beternak sapi potong 5-10 tahun $(41,7 \%)$. Walaupun di sisi lain pada umumnya berpendidikan rendah yaitu tingkat SD/sederajat $(55,6 \%)$ [2]. Kemudian pada penelitian ini dilanjutkan pembahasan karakteristik peternak yaitu tentang status usaha yang dikelola, jumlah ternak dimiliki/dipelihara dan status kepemilikan ternak. Hasil temuannya seperti yang tergambar pada Tabel 3.

Tabel 3. Karakteristik peternak sapi potong di Kabupaten Sijunjung

\begin{tabular}{lllcc}
\hline No. & Karakteristik & Uraian & Jumlah Responden & Persentase (\%) \\
\hline 1 & Status usaha & Usaha sampingan & 41 & 93,18 \\
& & Usaha upahan & 0 & 0 \\
\multirow{2}{*}{2} & \multirow{3}{*}{ Jumlah ternak yang dipelihara } & Usaha utama & 3 & 6.82 \\
& & $1-3$ ekor & 34 & 77,27 \\
& & $4-1$ ekor & 10 & 22,73 \\
3 & Kepemilikan ternak & Milik kelompok & 0 & 0 \\
& & Perseduaan & 5 & 11,36 \\
& & Milik sendiri & 27 & 27,27 \\
\hline
\end{tabular}

Sumber: Hasil Penelitian 2019

Tabel 3 di atas menjelaskan bahwa usaha peternakan sapi yang dilakukan oleh masyarakat peternak di Kabupaten Sijunjung pada umumnya masih sebagai usaha sampingan masyarakat (93,18\%). Data tersebut didukung dengan jumlah kepemilikan ternak (ternak yang dipelihara) yang hanya 1-3 ekor sapi $(77,27 \%)$ per peternak. Peternak memelihara ternak sapi hanya sebagai pengisi waktu luang setelah mereka dari sawah, ladangatau pekerjaan lainnya. Selain itu ternak sapi juga sebagai tabungan dan kebiasaan turun temurun yang telah dilakukan dari nenek moyang. Namun demikian, sapi yang 
dipelihara tersebut pada umumnya adalah milik peternak itu sendiri $(61,36 \%)$. Sebagian lainnya adalah ternak perseduaan dan ternak yang dimiliki kelompok.

Kondisi peternakan sapi di Kabupaten Sijunjung selaras dengan yang terjadi di Indonesia pada umumnya, bahwa lebih dari 9o\%, sapi diusahakan oleh peternakan rakyat dengan skala kecil, modal lemah serta masih bersifat usaha sampingan [4]. Dengan kondisi ini, tentu usaha peternakan sapi dilakukan dengan kurang serius sehingga mengakibatkan produktifitas yang dihasilkan rendah.

\subsection{Sistem Pemeliharaan}

Sistem pemeliharaan yang dimaksudkan adalah bagaimana cara masyarakat Kabupaten Sijunjung memperlakukan ternak sapinya. Sistem pemeliharaan sapi potong dapat dibedakan menjadi 3, antara lain sistem pemeliharaan ekstensif, semi intensif dan intensif [5]. Sistem ekstensif semua aktivitasnya dilakukan di padang pengembalaan yang sama. Sistem semi intensif adalah memelihara sapi untuk digemukkan dengan cara digembalakan dan pakan disediakan oleh peternak, atau gabungan dari sistem ekstensif dan intensif. Sementara sistem intensif adalah sapi-sapi dikandangkan dan seluruh pakan disediakan oleh peternak. Lebih rinci, sistem pemeliharaan sapi potong di Kabupaten Sijunjung dapat dilihat pada Tabel 4 .

Tabel 4. Sistem pemeliharaan ternak sapi potong di Kabupaten Sijunjung

\begin{tabular}{|c|c|c|}
\hline Uraian & Jumlah Responden & $\%$ \\
\hline Ekstensif & 14 & 31,82 \\
\hline Semi Intensif & 20 & 45,45 \\
\hline \multirow[t]{2}{*}{ Intensif } & 10 & 22,73 \\
\hline & 44 & 100 \\
\hline
\end{tabular}

Sumber: Hasil penelitian 2019

Dari hasil penelitian di lapangan ditemukan bahwa pada umumnya peternak sapi di Kabupaten Sijunjung memelihara ternaknya dengan sistem semi intensif $(45,45 \%)$. Sistem pemeliharaan semi intensif disini dilakukan sedikit berbeda. Sapi memang memiliki kandang tapi dengan tipe kandang yang sangat sederhana dan dikandangkan pada malam hari. Kemudian diberikan pakan tambahan berupa rumput dan sesekali dedak. Sebagian lainnya $(31,82 \%)$ ternak sapi dibiarkan lepas bebas di alam. Tidak ada kandang khusus dan pakan tambahan yang diberikan. Tujuan pemeliharaan sistem ini bukanlah murni untuk penggemukan, melainkan hanya sebagai tabungan, sambilan dan budaya saja. Hanya 22,73\% dari responden memelihara sapinya dengan serius dan intensif.

\subsection{Sistem Pengelolaan Pakan}

Dalam usaha peternakan sapi, pakan adalah salah satu elemen penting. Pakan ternak untuk budidaya sapi merupakan faktor yang penting untuk meningkatkan produksi [6]. Pada peternakan rakyat di Indonesia, pada umumnya sapi diberikan hijauan berupa rumput dan leguminosa. Kemudian diberikan pakan tambahan berupa konsentrat dan dilengkapi dengan mineral. Di Kabupaten Sijunjung jenis pakan yang diberikan pada ternak sapi potong dapat dilihat pada Tabel 5 .

Tabel 5. Jenis pakan ternak yang diberikan peternak sapi potong di Kabupaten Sijunjung

\begin{tabular}{lcc}
\hline \multicolumn{1}{c}{ Uraian } & $\begin{array}{c}\text { Jumlah } \\
\text { Responden }\end{array}$ & $\%$ \\
\hline Hijauan merumput & 17 & 38,64 \\
Hijauan merumput dan potong & 21 & 47,73 \\
Hijauan dan konsentrat & 6 & 13,64 \\
\hline & 44 & 100 \\
\hline
\end{tabular}

Sumber: Hasil penelitian 2019

Dari hasil penelitian, ditemukan bahwa pada umumnya pakan yang diberikan peternak adalah rumput lapangan kombinasi antara merumput dengan rumput potong $(47,73 \%)$. Karena ada sebagian usaha dikelola secara ekstensif, maka pakan rumput yang diberikan hanyalah rumput hasil merumput sendiri oleh sapi tersebut $(38,64 \%)$. Hanya $6 \%$ diantara responden yang memberikan pakan pada ternaknya berupa rumput ditambah konsentrat. Pada hal pertambahan bobot sapi lebih tinggi dengan waktu penggemukan yang relatif singkat bila sapi diberi ransum yang terdiri dari konsentrat dan hijauan [7].

Sementara untuk jumlah pakan yang diberikan oleh peternak, selaras dengan jenis pakan yang diberikan, ternak yang pakannya hanya dari hasil merumput, volume pakan yang dikonsumsi tidak menjadi perhatian oleh peternak karena ternaknya dilepas. Seperti itu juga ternak yang pakannya hasil merumput ditambah rumput hasil potong, volume pemberian pakannya juga tidak menjadi perhatian oleh peternak. Peternak pada umumnya memberikan pakan sesuai kemampuan tanpa mengindahkan aturan teknis volume pakan yang diberikan. Selebihnya, peternak memberikan pakan kombinasi hijauan $10 \%$ dan konsentrat $1 \%$ dari berat badan ternak sapi. Secara teknis, rata-rata kebutuhan konsumsi pakan bagi sapi potong yaitu $10 \%$ dari berat badan [8].

\subsection{Sistem Pengelolaan Reproduksi}

Keberhasilan usaha sapi potong salah satunya ditentukan oleh keberhasilan reproduksi. Apabila pengelolaan reproduksi ternak dilakukan dengan tepat maka akan menghasilkan kinerja reproduksi yang baik yaitu peningkatan angka kebuntingan dan jumlah kelahiran pedet. Ada beberapa sistem perkawinan yang selama ini sudah dikenal di masyarakat peternak, seperti kawin alam, inseminasi 
buatan dan transfer embrio. Di Kabupaten Sijunjung transfer embrio belum dilakukan oleh peternak. Selengkapnya dapat dilihat pada Tabel 6 berikut:

Tabel 6. Sistem Pengelolaan Reproduksi Sapi Potong di Kabupaten Sijunjung

\begin{tabular}{lcc}
\hline \multicolumn{1}{c}{ Uraian } & $\begin{array}{c}\text { Jumlah } \\
\text { Responden }\end{array}$ & $\%$ \\
\hline $\begin{array}{l}\text { Kawin alam } \\
\text { sembarangan }\end{array}$ & 0 & 0 \\
$\begin{array}{l}\text { Kawin alam dengan } \\
\text { jantan pemacek }\end{array}$ & 22 & 50 \\
$\begin{array}{l}\text { Inseminasi Buatan } \\
\end{array}$ & 22 & 50 \\
\hline
\end{tabular}

Sumber: Hasil Penelitian 2019

Dari hasil data di lapangan, peternak sapi potong di Kabupaten Sijunjung setengahnya menggunakan kawin alam dengan jantan pemacek dan setengah lagi melalui inseminasi buatan. Sudah tidak ada kawin alam sembarangan yang tidak terpantau oleh peternak.

Beberapa penelitian mengatakan bahwa inseminasi buatan memungkinkan untuk menghasilkan lebih banyak keturunan dari masingmasing pejantan, dibandingkan kawin alam [9]. Inseminasi buatan memiliki beberapa keuntungan utama yaitu perbaikan genetik, mengontrol penyakit kelamin pada ternak (venereal diseases), adanya catatan perkawinan/inbreeding yang teliti dan menjaga kesehatan induk dari pejantan dalam satu kelompok [10].

\subsection{Sistem Pemasaran}

Pemasaran pada prinsipnya merupakan proses kegiatan penyaluran produk yang dihasilkan oleh produsen agar dapat sampai kepada konsumen. Bagi produsen sapi potong, baik perusahaan peternakan maupun peternakan rakyat pemasaran mempunyai peran yang penting. Di Kabupaten Sijunjung, ternak sapinya dijual ke toke ternak atau pedagang pengumpul, dibawa sendiri ke pasar ternak, dan dijual ke panitia kurban. Selengkapnya pada tabel berikut:

Tabel 7. Sistem Pemasaran Ternak Sapi Potong di Kabupaten Sijunjung.

\begin{tabular}{lcc}
\hline \multicolumn{1}{c}{ Uraian } & $\begin{array}{c}\text { Jumlah } \\
\text { Responden }\end{array}$ & $\mathbf{\%}$ \\
\hline Toke ternak/pedagang pengumpul & 39 & 88,64 \\
Dibawa ke pasar ternak & 4 & 9,09 \\
Panitia kurban & 1 & $\mathbf{2 , 2 7}$ \\
\hline
\end{tabular}

Sumber: Hasil Penelitian 2019

Tabel 7 di atas menjelaskan bahwa sebagian besar peternak menjual sapinya ke pedagang pengumpul atau di Sumatera Barat dikenal dengan sebutan toke ternak $(88,64 \%)$. Walaupun di kabupaten ini terdapat Pasar Ternak Palangki, namun masih sedikit peternak yang menjual langsung ternaknya ke pasar ternak tersebut (9,09\%). Diskusi dengan peternak di lapangan, hal itu disebabkan jarak yang cukup jauh dengan pasar ternak, ketidakadaan mobil pengangkut dan ketidak mengertian peternak masuk ke pasar ternak. Karena pasar ternak di Sumatera Barat sampai saat ini masih menggunakan Sistem Barosok atau Marosok dalam transaksi jual belinya. Marosok merupakan tradisi tawar menawar hewan ternak menggunakan jari-jari, setiap jari melambangkan angka tertentu. Untuk menjaga kerahasiaan permainan jari antara pembeli dan penjual yang sedang tawar menawar maka jarijari akan ditutup dengan handuk, sarung atau jaket [11].

\section{Kesimpulan}

Hasil penelitian dapat disimpulkan bahwa usaha peternakan sapi potong di Kabupaten Sijunjung masih usaha sampingan masyarakat (93,18\%), jumlah ternak yang dipelihara 1-3 ekor per peternak (77,27\%) dan pada umumnya merupakan sapi milik sendiri $(61,36 \%)$. Sistem pemeliharaan ternak pada umumnya dengan sistem semi intensif $(45,45 \%)$ dengan pakan yang diberikan adalah hijauan dengan merumput ditambah hijauan hasil pemotongan (47,73\%). Sistem reproduksi menggunakan kawin alam dengan jantan pemacek (50\%) dan inseminasi buatan $(50 \%)$ serta pemasaran ternak masih melalui toke ternak/pedagang pengumpul $(88,64 \%)$.

\section{Referensi}

[1] Badan Pusat Statistik Kabupaten Sijunjung. 2017. Sijunjung Dalam Angka. BPS Kabupaten Sijunjung. Kabupaten Sijunjung.

[2] Putra, Riza Andesca. 2016. Analisa Potensi Wilayah untuk Pengembangan Peternakan Sapi Potong di Kabupaten Sijunjung. Jurnal Agrotropical Volume 6. Kabupaten Sijunjung.

[3] Wirartha, I Made. 2006. Metode Penelitian Sosial Ekonomi. Penerbit Andi. Yogyakarta.

[4] Yusdja, Y. dan N. Ilham. 20o6. Arah kebijakan pembangunan peternakan rakyat. Pusat Analisis Sosial Ekonomi dan Kebijakan Pertanian. Analisis Kebijakan Pertanian 4: 18-38.

[5] Susilorini, E. T. 2008. Budi Daya 22 Ternak Potensial. Penebar Swadaya. Jakarta

[6] Darmono. 1993. Tatalaksana Usaha Sapi Kreman. Kanisius. Jakarta.

[7] Setiadi, B. 2010. Beternak Sapi Pedaging dan Masalahnya. Aneka Ilmu. Semarang.

[8] Sugeng, Y.B., 2003. Pembiakan Ternak Sapi. Gramedia. Jakarta. 
[9] Hafez E. S. E. and Hafez, B. 20oo. Reproduction In Farm Animal. $7^{\text {th }}$ edition. Leafebiger. Philadelphia.

[10] Toelihere, M. R. 1993. Inseminasi Buatan Pada Ternak. Angkasa. Bandung.

[11] Fadhilah, S. 2017. Pola Komunikasi Tradisi Marosok Antara Sesama Penjual dalam Budaya Dagang Minangkabau. Jurnal Kajian Komunikasi Volume 05 Nomor 02. Sumedang 